\title{
SPECIALIZED PREDATION ON ORIBATID MITES BY TWO SPECIES OF THE ANT GENUS MYRMECINA (HYMENOPTERA: FORMICIDAE)
}

\author{
By KeIICHI Masuko \\ School of Business Administration \\ Senshu University, \\ Kawasaki 214, Japan
}

\begin{abstract}
Specialized predation on oribatid mites was confirmed in two Japanese species of the myrmicine genus Myrmecina, the first instance in the Formicidae. Using the mouthparts and legs, a worker skillfully tears a hole in the oribatid body and gives the partly dismembered prey to a larva. During food preparation workers bend the gaster forward deeply and raise their anterior body thus making the working posture stable; both seem necessary for handling such round slippery prey as oribatid mites. The larva of Myrmecina has a peculiarly elongate head which it inserts into an oribatid body and consumes the contents.
\end{abstract}

\section{INTRODUCTION}

Although it is generally believed that most ants are polyphagous, there are many species with predatory habits exclusively or chiefly limited to particular prey (Hölldobler and Wilson 1990; Masuko 1992). Among such specialist predators are collembolan predators in the tribe Dacetini (subfamily Myrmicinae). Their predation is facilitated by highly specialized morphology and behavior (Brown and Wilson 1959; Dejean 1982, 1985a, b; Masuko 1984). Collembolans are so numerous in forest leaf litter that they are called "soil plankton" and many arthropods feed on them (Aoki 1973). In contrast, the mites of Oribatida (Cryptostigmata), or oribatid mites, which are comparable to the Collembola in their abundance, have few known predators except for beetles in the families Pselaphidae (Park 1947), Ptiliidae (Riha 1951) and

Manuscript received 1 March 1994. 
Scydmaenidae (Schuster 1966). No ant species have been reported to prey regularly on oribatids. The hard slippery exoskeletons of oribatids, especially of adults, sometimes in combination with rolling-up behavior in which all appendages are withdrawn into the body capsule, seem to provide protection from predators. However, I found that two species of ants in the genus Myrmecina feed largely on this group of mites. Details of this specialized predation are described here and the adaptations of morphology and behavior in both adult and larval ants are discussed.

\section{MATERIALS AND Methods}

Ants of the genus Myrmecina are distributed over the tropical and temperate regions, and are most diverse and abundant in the Indo-Australian region where about 20 species have been described (Ogata and Terayama1992). Of the four species collected from Japan, I found that two-Myrmecina graminicola nipponica Wheeler and Myrmecina flava Terayama-fed on oribatid mites. Both Myrmecina are relatively small ants: the worker of $M . g$. nipponica is $3 \mathrm{~mm}$ long and that of $M$. flava $2.5 \mathrm{~mm}$ long. Colonies of these two species were collected in evergreen broadleaf forest at Cape Manazuru, Kanagawa Prefecture. In this region M. g. nipponica is monogynous while $M$. flava is polygynous (often with microgynes).

In the laboratory four M. g. nipponica and two M. flava colonies were cultured each in a glass covered polystyrene container $(10 \times 11 \times 2 \mathrm{~cm})$. The bottom of the nest was covered with a layer of gypsum mixed with activated charcoal; a depression was excavated as a brood chamber. The activities of ants were observed using a stereomicroscope.

For scanning electron microscopy, ant larvae were fixed in Kahle's solution (Barbosa 1974), followed by $80 \%$ ethanol. Specimens were then dehydrated, treated with hexamethyldisilazane (Nation 1983), dried in the air, mounted on stubs using tape that is sticky on both sides, and coated with gold-palladium. Observation was made in a J.E.O.L. JSM-25 and an Hitachi S405 microscopes. 
Results

Field observation

Both species nest in solid soil 10-20 cm deep under a thick layer of leaf litter in the forest. The first suggestion of oribatid feeding by Myrmecina was observed in the field in the winter of 1982 when I found several dozens arthropod remains in a narrow irregular space in the soil. This space was a refuse chamber adjacent to a $M . g$. nipponica nest chamber, and contained chitinous fragments of arthropods, later identified as other ants, adult coleopterans and oribatid mites. Most oribatids were opened in a typical manner, i.e., the anterior region of the ventral surface was broken open (Fig. 1). This is the region where the mites' mouthparts and leg bases are found. After this find, nests were examined carefully to locate the refuse chambers. Refuse chambers were located in 7 of $35 \mathrm{M}$. g. nipponica nests and in 1 of 9 M. flava nests in 1982 and 1983. Oribatid remains were found in each of these refuse sites and most bodies had been broken open anteroventrally or had lost all sternites. Identified oribatid species are listed in the Appendix. Among them, the species Ceratozetella imperatoria (Aoki) was numerous in the refuse of $M$. g. nipponica. In a nest of this species excavated on 9 January 1983, 103 C. imperatoria remains were found, whereas each of the other 5 identified oribatid species was represented by only 1 or a few. In contrast, $C$. imperatoria was absent from the refuse of $M$. flava. Furthermore, in prey preference tests conducted in the laboratory, $M$. flava rejected $C$. imperatoria. A small number of remains of some gamasid mites (Mesostigmata) were also found in the refuse of both species (see Appendix).

During April to October the inside of brood chambers was carefully surveyed with a hand loupe in order to catch ant larvae in the act of feeding on oribatid mites. In two nests of $M$. g. nipponica excavated in April 1983 I found larvae feeding on oribatid (Fig. 2) and gamasid mites; 2 in the first nest and 3 in the second. Four of the 5 larvae had inserted their heads into partly opened oribatids ( 3 C. imperatoria and 1 Rhysotritia ardua (C. L. Koch)) and one larva was feeding on a mesostigmatid mite. The larvae of the ant genus Myrmecina have an extremely elongate cranium. Details of the relationship between the feeding behavior of the larva and some of its morphology are discussed below. 


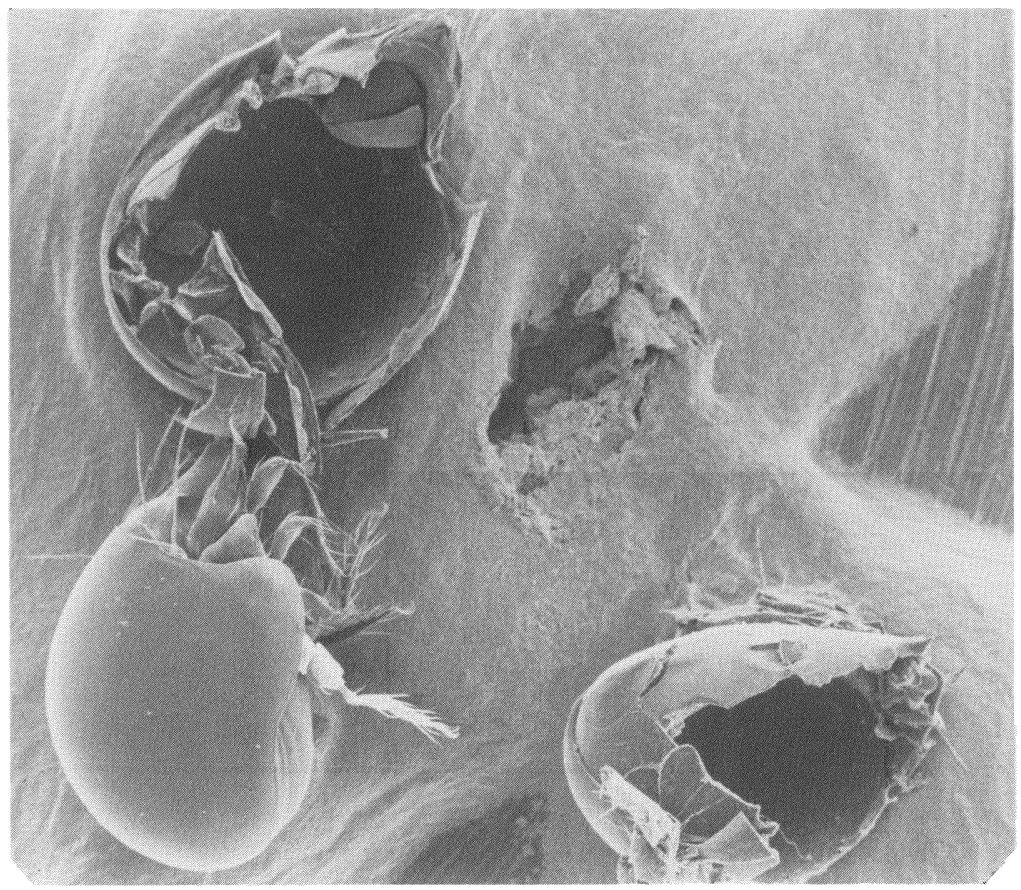

Fig. 1. Remains of two oribatid mites (Ceratozetella imperatoria) after predation by Myrmecina graminicola nipponica in the laboratory and an intact individual of the same species for comparison. The mite in upper left is in ventral view and the lower right one is in lateroventral view; the intact one is in lateral view. $B a r=1 \mathrm{~mm}$.

\section{Laboratory observation}

(1) Preference tests

Laboratory rearing and the results of food preference tests indicate that both $M$. g. nipponica and $M$. flava are polyphagous. I introduced small soil arthropods, which I had immobilized by partly crushing, into the foraging arena and observed whether they were retrieved by workers and fed to larvae. Both species accepted entomobryomorph collembolans, beetle larvae (Tenebrio molitor and Tribolium confusum), geophilomorph centipedes and terrestrial amphipods (Talitridae). Larvae of terrestrial isopods in families 


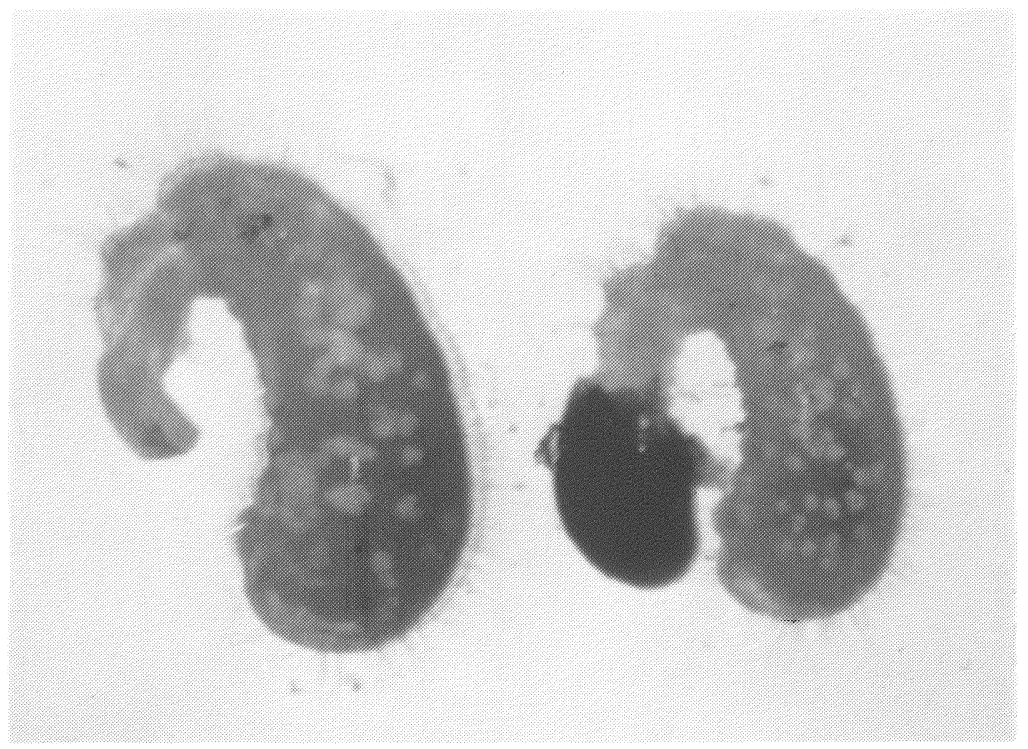

Fig. 2. Larvae of M. g. nipponica, one of which is inserting its head into an oribatid mite (Ceratozetella imperatoria). Both larvae are of the final instar and were preserved immediately in the field.

Ligiidae and Oniscidae were accepted, but those of family Armadillidiidae were rejected. I tested sugar solution on $M$. g. nipponica and workers readily accepted it. M. g. nipponica eagerly hunted intact Ceratozetella imperatoria, Gustavia microcephala (Nicolett) and Xylobates magnus Aoki; M. flava accepted the latter two but ignored $C$. imperatoria and Rhysotritia ardua. Remains of $R$. ardua were found in refuse dump in field nests of M. flava.

(2) Predatory behavior

When a worker of $M . g$. nipponica which was walking in the foraging arena touched an oribatid with its antennae, it began a conspicuous frenzied movement pattern which was not observed in any other context. The worker frantically repeated short runs and stops turning right or left alternately; within a few seconds she grasped the mite in her mandibles and carried it alive into the nest chamber. 


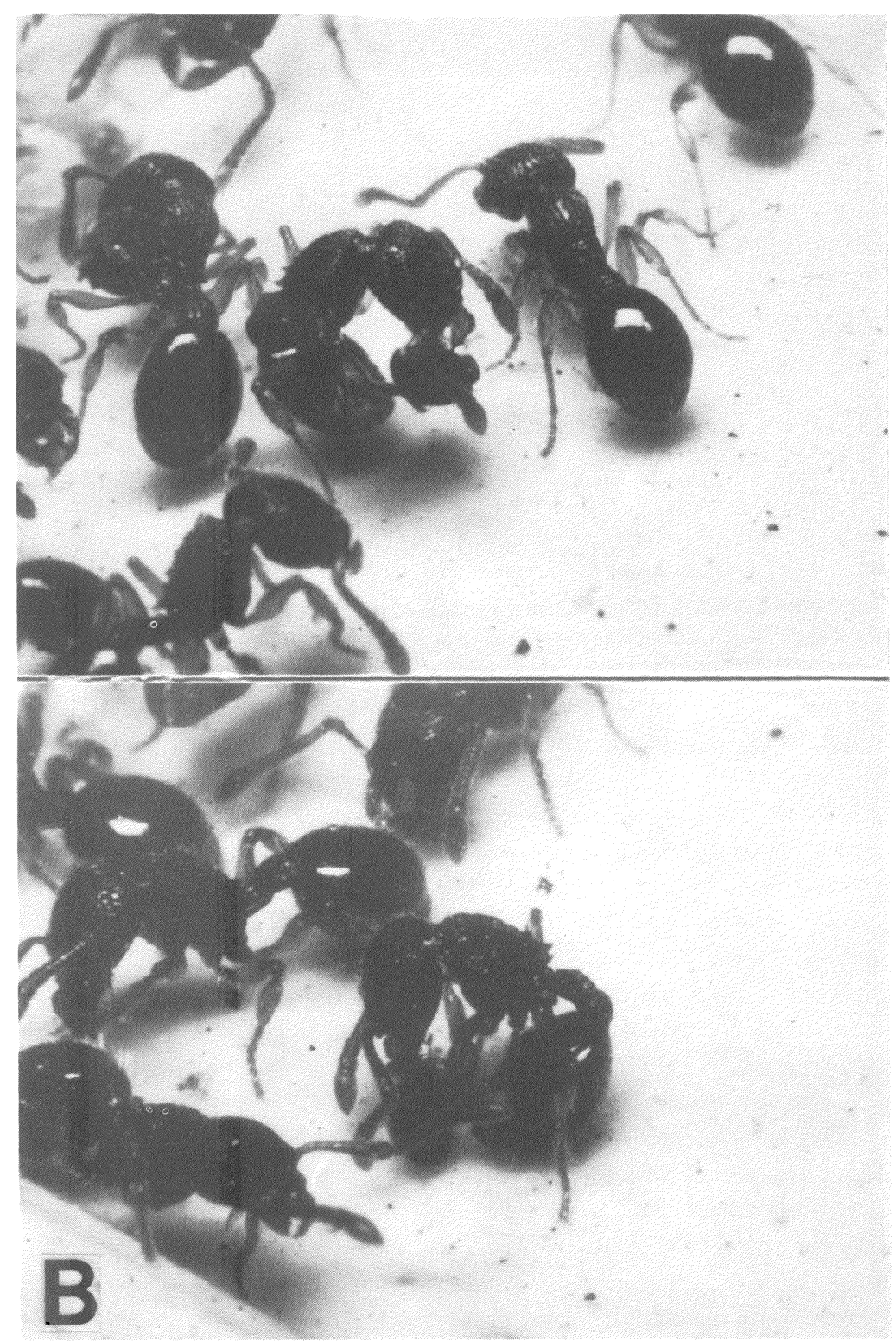

Fig. 3. A, B: Workers of $M$. g. nipponica dismembering oribatid mites in a laboratory nest. Note that the ant's gaster is bent forward but not brought into contact with the prey. 
Preparation of the prey was started by the forager or by another worker. The worker almost always bent the abdomen down and forward (Fig. 3), especially when preparing a relatively large mite such as C. imperatoria. However the tip of the abdomen was seldom directed at, or touched, the mite; it was directed at the floor. It seemed that this posture was required in order to raise the anterior half of the body, which facilitated handling a round slippery object with the mouthparts and legs. In this posture the ant stood on one middle and both hind legs. In addition the abdominal tip was usually on the floor. The prey was held ventrolaterally by the ant's two forelegs and posteriorly by a middle leg. The ant moved and rolled the mite while touching the mite with its lower mouthparts and sometimes pinching it with its mandibles. The ant would finally make a hole near the anteroventral portion of the mite body. After a hole was made in the mite, which often concurrently lost a third or fourth of the venter (Fig. 2), the worker gave it to a larva, pointing the opened portion to the larval head. If the mite was small the ant stood on both pairs of middle and hind legs and, without bending the body, used the only the forelegs and mouthparts to handle the mite, and sometimes it tried to crush the mite with its mandibles.

Some species of oribatid mites emitted a sticky substance that repelled Myrmecina workers. When touched on the mandibles or antennae with this substance, the ant retreated and rubbed that part against the substrate. A similar response was observed when the ants prepared a diplopod hatchling. The dismantling process was greatly delayed due to this repellent but in each instance the prey was finally eaten.

(3) Possible adaptations in the larva

Allometry of head

Figure 4A shows the final larval instar of $M$. g. nipponica. It has a peculiarly elongate head capsule (Fig. 5). The larva of Myrmecina puts its elongate head into the worker-made opening in an oribatid and consumes the contents.

I found four larval instars in M. g. nipponica and M. flava, based on the measurement of head and chaetotaxy using a SEM (Masuko, unpublished data). Comparison of the heads of the four instars indicated that elongation occurred in the region ventral to the 

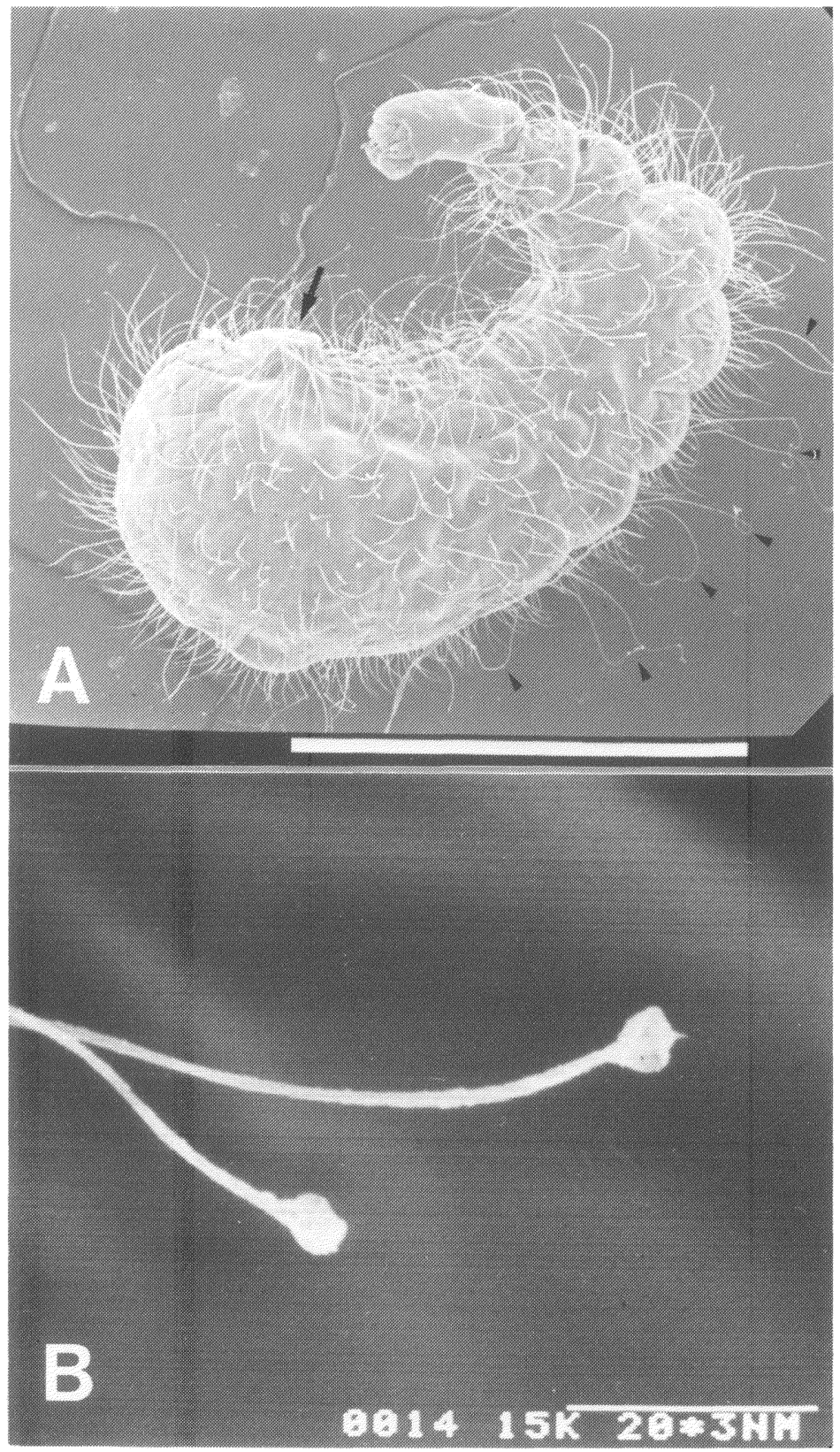
antennae (the frons, gena and gulla all lengthened disproportionately) (Fig. 5). To examine this development, an allometric relationship was obtained for the length and width of the head (Fig. 6). Allometry is expressed as $y=b x^{k}$ where $y$ and $x$ are linear measures of body parts and $\mathrm{k}$ and $\mathrm{b}$ are constants. This is equivalent to the logarithmic form as $\log \mathrm{y}=\log \mathrm{b}+\mathrm{k} \log \mathrm{x}$ (Wilson 1953). A total of $30 \mathrm{M}$. g. nipponica larvae (5 first instar, 6 second, 10 third and 9 fourth) were measured on SEM micrographs, giving rise to the following regression:

$$
\log \mathrm{y}=\log 20.56+0.409 \log \mathrm{x}
$$

where $\mathrm{y}$ and $\mathrm{x}$ are the head width and head length in $\mu \mathrm{m}\left(r^{2}=0.598\right.$; SE and $95 \%$ confidence interval of the constant $\mathrm{k}$ were 0.063 and 0.279-0.538; Sokal and Rohlf 1981: p.473). The constant k was less than unity, meaning that head length increases more than head width during larval development. This allemotric pattern of development of the head may be general in ant larvae. Thus, for comparison, a similar measurement using SEM was done with the myrmicine Manica yessensis. This ant is a generalist predator and also has four larval instars (Masuko, unpublished data). A total of 23 larvae ( 3 first, 5 second, 10 third and 5 fourth instar) were measured, giving the following allometric regression:

$$
\log \mathrm{y}=\log 3.98+0.787 \log \mathrm{x}
$$

where again $\mathrm{y}$ is head width and $\mathrm{x}$ is head length in $\mu \mathrm{m}\left(r^{2}=0.888\right.$; SE and 95\% confidence interval of the constant $\mathrm{k}$ were 0.061 and $0.660-0.914)$. Although the comparison is limited, the constant $\mathrm{k}$ in $M$. g. nipponica is farther from unity. It may be related to the width of the mites upon which Myrmecina larvae feed.

\section{Specialization of dorsal hairs}

Observation with SEM showed that each first through fifth abdominal segment bears a row of four long spatulate tipped hairs (Fig. 4A, B); two are dorsal and one is on each dorsolateral

Fig. 4. A: Final instar larva of $M$. g. nipponica. Arrow indicates a swelling on the ventral surface near the posterior end. Small arrowheads point to the dorsal, long flexuous hairs with spatulate tips. B: Spatulate tips of the hairs indicated in A. A, bar $=1 \mathrm{~mm}$; $B$, bar $=20 \mu \mathrm{m}$. 


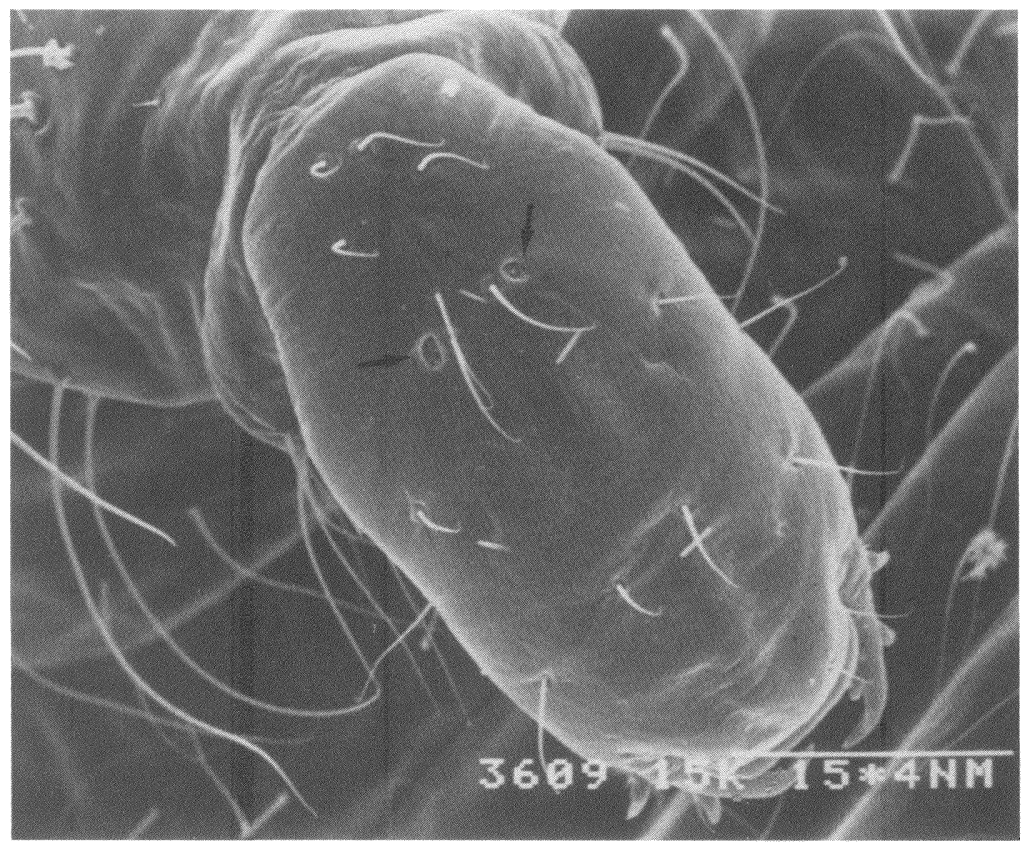

Fig. 5. Anterodorsal view of head of the final instar larva of $M$. g. nipponica. Arrows point to the antennae. Elongation of head occurs in the area ventral to the antennae. Scale $=150 \mu \mathrm{m}$.

surface; on the sixth segment, two are dorsal but the dorsolateral hairs are shorter and simple. Due to these long hairs larvae are quite easily attached to each other and to wall or ceiling in natural and artificial nests. More importantly, owing to the location, direction and structure of these hairs, they serve to keep larvae in the right position, that is, the larva lies on its back. The dorsal hairs act as supports. In fact, it is easy to place the larva in this position by only a slight touch with a pair of tweezers. Also in natural nests, they are placed in this posture on the flat surface of the floor or suspended from the ceiling.

\section{Discussion}

Because the field and laboratory data are limited, the degree of oligophagy on oribatid mites in Myrmecina remains to be deter- 


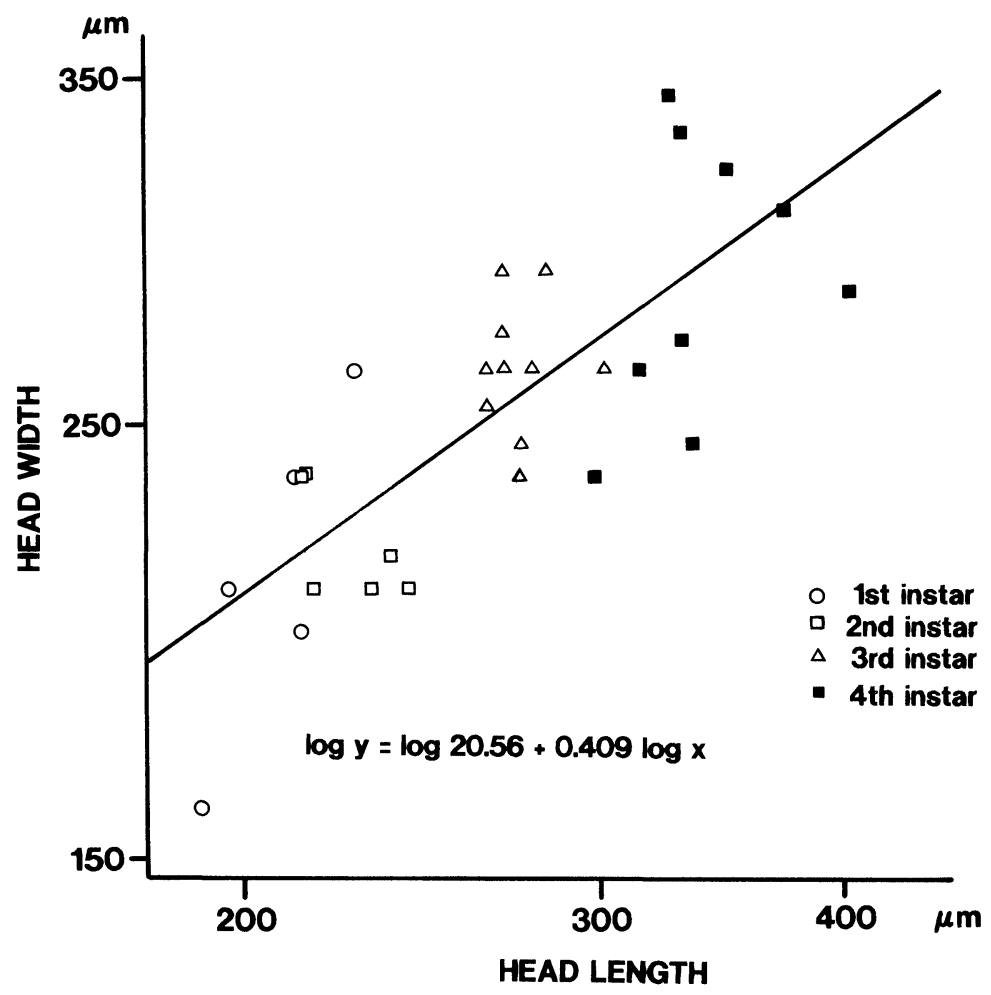

Fig. 6. Development of head in the larva of $M$. g. nipponica. Head length and head width of the 1st to 4 th instars were measured on SEM micrographs.

mined. Laboratory observations and information from refuse in wild nests strongly suggest their specialization on oribatid mites, and both adults and larvae seem to have behavioral and morphological adaptations to this specialized feeding. M. g. nipponica and $M$. flava scavenge a variety of arthropods in addition to preying on oribatids. Specialization would not necessarily lead to strict narrowing of the prey regime. Rather, a combination of specialization on a certain prey group and scavenging on a broad spectrum of organisms might be common in specialist predators, e.g. members of Dacetini (Masuko 1984). 
Species of Myrmecina are reported to be non-stinging ants (Maschwitz 1964). Kugler (1979) made a study of the sting apparatus of the Myrmicinae and distinguished four groups based on the form and development of the sting. He classified Myrmecina graminicola in the group whose sting is short and weakly sclerotized. In $M$. g. nipponica the worker had a short and weakly sclerotized sting. No stinging acts were observed when this ant attacked any living organism.

In addition to the morphology, the posture taken by the Myrmecina worker at the time of dismembering oribatids is of interest. Raising the anterior body and flexing the abdomen downward and forward seem to be requisite for handling round slippery prey with the legs and mouthparts. This behavior reminds me of a similar behavior related to handling spherical prey in Discothyrea and Proceratium in the ponerine tribe Ectatommini. These adults have abdominal tips pointed downward and slightly anteriorly and a shortened trunk which contrasts with the long straight body typical in ponerines. The curved abdomen is used to support the slippery arthropod egg while it is handled with the forelegs (Brown 1974; Hölldobler and Wilson 1990; Masuko 1992). Brown (1992) reported that in another ectatommine, Gnamptogenys ingeborgae, the gaster points anteroventrally and is required for prey handling: the worker, using its mandibles and the gastral tip as a fulcrum, breaks off the head of the specialized prey, polydesmid millipedes. Observation of Myrmecina and these ectatommine ants suggests that the lift of the head and thorax and the forward flex of the gaster, both behaviorally and morphologically, are adaptations needed to manipulate these specialized prey which are difficult to handle.

The peculiarly elongate head of Myrmecina americana and two species of Pristomyrmex are described by Wheeler and Wheeler (1954) in their study of the larvae of the tribe Myrmecini. The manner of head elongation is similar in these closely related genera: the head region expands between the antennae and the mouthparts. Details of the food habits of Pristomyrmex are not known. The head of the larva suggests some specialization of diet.

Finally, Wheeler and Wheeler (1955) describe a similarly elongated head in the larvae of Adelomyrmex (=Apsychomyrmex). Adelomyrmex is placed formally in Leptothoracini in some literature 
(e.g. Wheeler and Wheeler 1985), but, according to Brown (pers. comm.), it is more closely related to Myrmecina than to any leptothoracines. He also found a dense mass of dead mite carcasses placed in the refuse dump in two wild nests of a new species of Adelomyrmex which he collected in Colombia. The mites were of two different groups, one oribatid, and the other undetermined, but the dead bodies of both groups were damaged in the same way: "a large, ragged hole was found near the caudal end of the body, but to either the right or left of the midline" (underlined by Brown).

If oribatid mite feeding is only seen in a small number of ant species consisting of members of Myrmecina, Adelomyrmex and only a few others, this prey-predator relationship would contrast with the situation for another abundant "soil plankton", collembolans, whose specialized ant predators, the dacetine ants consist of about 400 species (Bolton 1983). Ant predation on oribatid mites may have evolved fewer times and predatory taxa diversified less because of the extreme difficulty in handling these heavily armored organisms.

\section{ACKNOWLEDGMENTS}

I thank J. Aoki and T. Takahashi for identification of oribatids and K. Ishikawa for that of gamasids. M. Terayama and B. Bolton readily provided references and useful information. J. Aoki, W. L. Brown and J. Wheeler kindly read through the manuscript. I am especially indebted to J. Wheeler who offered valuable criticism on my study and W. L. Brown for providing his unpublished observation. I also thank T. Matsumoto for facilities enabling preparation of the manuscript in his laboratory.

\section{REFERENCES}

Aoki, J. 1973. Soil Zoology. Hokuryu-kan, Tokyo. (In Japanese)

Barbosa, P. 1974. Manual of Basic Techniques in Insect Histology. Autumn Publishers, Amherst, MA.

Bolton, B. 1983. The Afrotropical dacetine ants (Formicidae). Bull. Br. Mus. Nat. Hist. (Ent.) 46:267-416.

Brown, W. L., Jr. 1974. A remarkable new island isolate in the ant genus Proceratium (Hymenoptera: Formicidae). Psyche 81:70-83.

. 1992. Two new species of Gnamptogenys, and an account of millipede predation by one of them. Psyche 99:275-289.

Brown, W. L., Jr., and Wilson, E. O. 1959. The evolution of the dacetine ants. Quart. Rev. Biol. 34:278-294. 
Dejean, A. 1982. Etude éco-éthologique de la prédation chez les fourmis du genre Smithistruma (Formicidae, Myrmicinae, Dacetini) I. Effets du milieu sur le choix des proies chez Smithistruma truncatidens Brown. Insect. Sci. Application 3:245-249.

—_ 1985a. Etude éco-éthologique de la prédation chez les fourmis du genre Smithistruma (Formicidae, Myrmicinae, Dacetini) II. Attraction des proie principales (Collembolan). Insect. Soc. 32:158-172.

- $1985 \mathrm{~b}$. Etude éco-éthologique de la prédation chez les fourmis du genre Smithistruma (Formicidae, Myrmicinae, Dacetini) III. La capture des proies chez $S$. emarginata. Insect. Soc. 32:241-256.

Hölldobler, B., and Wilson, E. O. 1990. The Ants. Belknap Press of Harvard Univ. Press, Cambridge, MA.

Kugler, C. 1979. Evolution of the sting apparatus in the myrmicine ants. Evolution 33:117-130.

Maschwitz, U. 1964. Alarm substances and alarm behavior in social Hymenoptera. Nature 204:324-327.

Masuko, K. 1984. Studies on the predatory biology of Oriental dacetine ants (Hymenoptera: Formicidae) I. Some species of Strumigenys, Pentastruma, and Epitritus, and a Malaysian Labidogenys, with special reference to hunting tactics in short-mandibulate forms. Insect. Soc. 31:429-451.

- 1992. Ants as the leading predators and their skill of hunting. In: The Committee recommended Dr. Mark Konishi for the 1990 International Prize for Biology (ed.), Perspectives in Neuroethology, pp.122-134. Kyoto University, Kyoto.

Nation, J. L. 1983. A new method using hexamethyldisilazane for preparation of soft insect tissues for scanning electron microscopy. Stain Technol. 58:347-351.

Ogata, K., and Terayama, M. 1992. The genus Myrmecina. In: Myrmecological Society of Japan (ed.) A Guide for the Identification of Japanese Ants III. Myrmicinae and Supplement to Leptanillinae (Hymenoptera: Formicidae), pp.54-56. Myrmecological Society of Japan, Tokyo. (In Japanese)

Park, O. 1947. Observations on Batrisodes (Coleoptera: Pselaphidae), with particular reference to the American species east of the Rocky Mountains. Bull. Chicago Acad. Sci. 8:43-132.

Riha, G. 1951. Zur Ökologie der Oribatiden in Kalksteinböden. Zool. Jb. Syst. $80: 408-450$.

Schuster, R. 1966. Über den Beutefang des Ameisenkäfers Cephennium austriacum Reiter. Naturwissenschaften 53:113-114.

Sokal, R. R., and Rohlf, F. J. 1981. Biometry. W. H. Freeman and Co., San Francisco.

Wheeler, G. C., and Wheeler, J. 1954. The ant larvae of the myrmicine tribe Myrmecinini. Proc. Entomol. Soc. Wash. 56:126-138.

- 1955. The ant larvae of the myrmicine tribe Leptothoracini. Ann. Entomol. Soc. Amer. 48:17-29.

- 1985. A simplified conspectus of the Formicidae. Trans. Amer. Entomol. Soc. 111:255-264.

Wilson, E. O. 1953. The origin and evolution of polymorphism in ants. Quart. Rev. Biol. 28:136-156. 
APPENDIX

Identification of mites (A) found as remains in refuse sites and (B) being fed on in brood chambers of field nests, and (C) fed on in the laboratory.

A. Remains of oribatid mites (Oribatida) and gamasid mites (Gamasida) found in refuse sites of ant nests

M. g. nipponica

Oribatida

Ceratozetella imperatoria (Aoki), Rhysotritia ardua (C. L. Koch), Ceratozetes mediocris Berlese, Planaphacarus kugohi (Aoki), Caradodes sp., Xylobates sp., Damaeidae gen. sp.

Gamasida

Macrocheles sp., Parasitus sp.

M. flava

Oribatida

Rhysotritia ardua

Gamasida

Parholaspis sp., Uropoda sp.

B. Oribatid mites found being fed on in field nests of $M . g$. nipponica

Ceratozetella imperatoria, Rhysotritia ardua

C. Oribatid mites fed on in laboratory

M. g. nipponica

Ceratozetella imperatoria, Gustavia microcephala (Nicolett), Xylobates magnus Aoki

M. flava

Gustavia microcephala, Xylobates magnus 

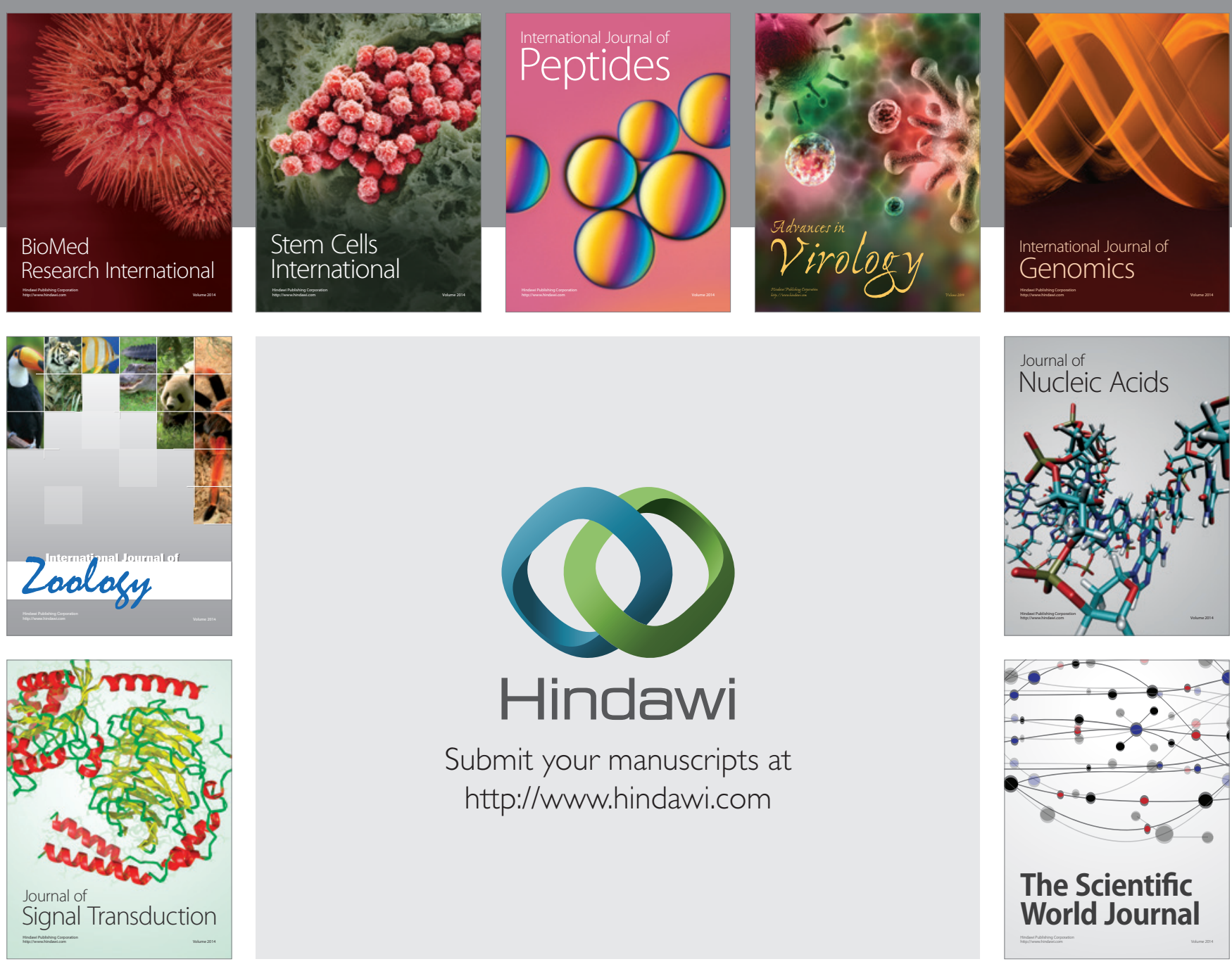

Submit your manuscripts at

http://www.hindawi.com
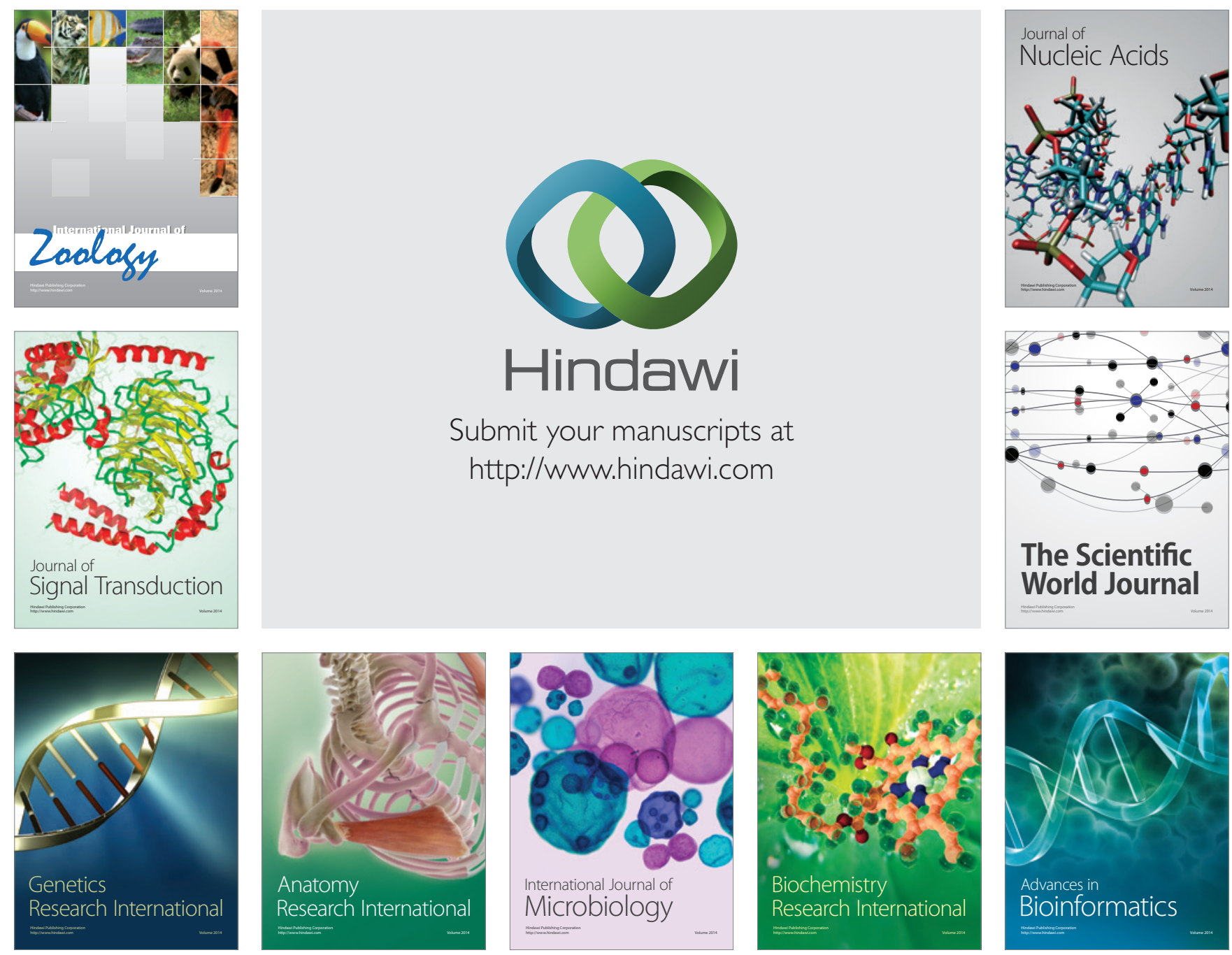

The Scientific World Journal
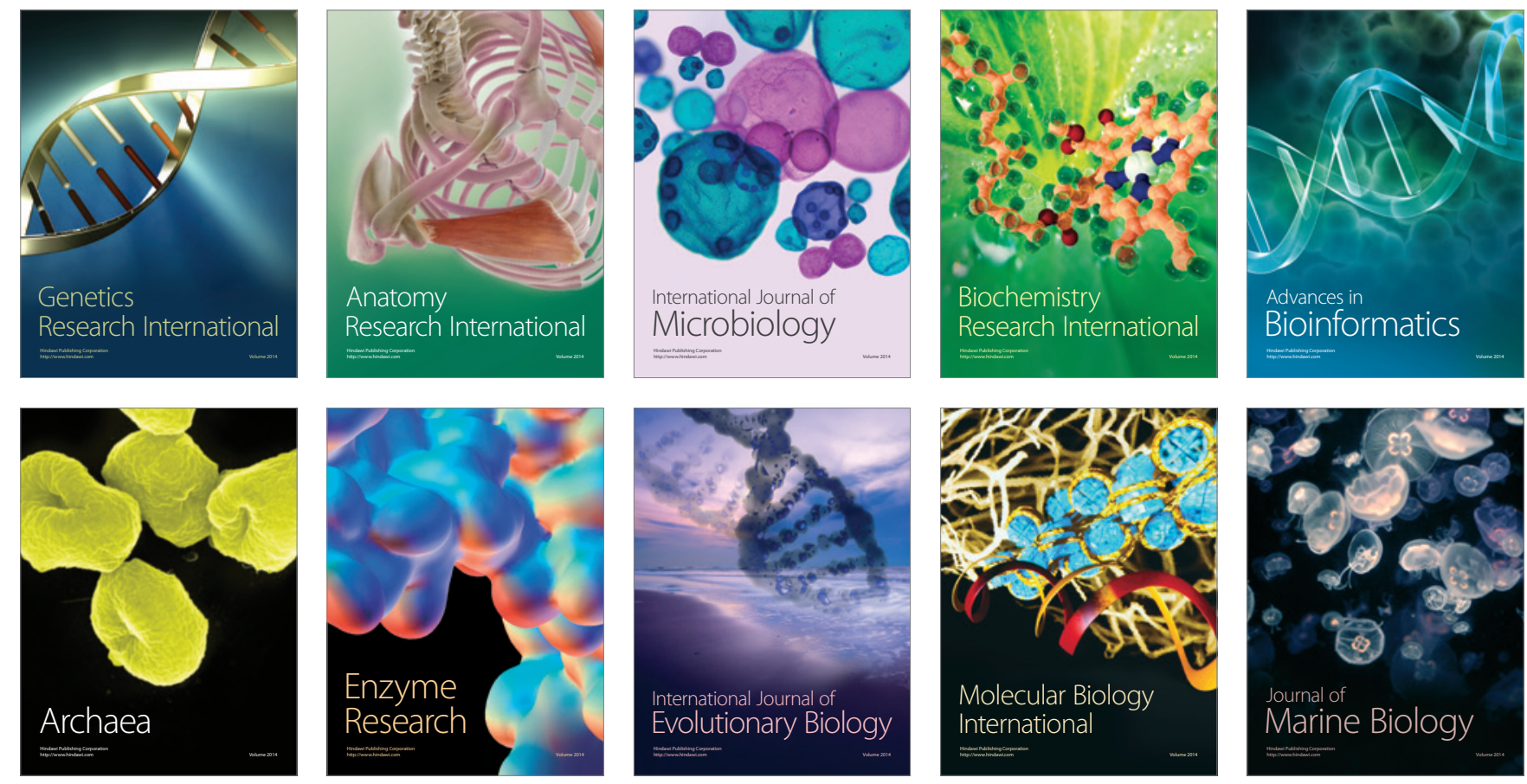